\title{
Structure Homogeneity and Thermal Stability of Austempered Ductile Iron
}

\author{
M. GÓRNY, Ł. GONDEK, E. TYRAŁA, G. ANGELLA, and M. KAWALEC
}

\begin{abstract}
Solid-state transformation during heat treatment is of great practical importance because it significantly affects the final structure, properties, and thermal stability of cast components. The present study highlights the issue of structure formation and its effect on the thermal stability of high-quality cast iron, namely, austempered ductile iron (ADI). In this study, experiments were carried out for castings with a $25-\mathrm{mm}$-walled thickness and under variable heat treatment conditions, i.e., austenitization and austempering within ranges of $850{ }^{\circ} \mathrm{C}$ to $925^{\circ} \mathrm{C}$ and $250{ }^{\circ} \mathrm{C}$ to $380{ }^{\circ} \mathrm{C}$, respectively. The X-ray diffraction (XRD) investigations were carried out within a range of $-260{ }^{\circ} \mathrm{C}$ to $+450{ }^{\circ} \mathrm{C}$ to study the structure parameters related to the XRD tests, which provided information related to the phase participation, lattice parameters, and stresses in the microstructure as well as with an expansion of the crystal lattice. The results also provide insight into the role of the structure and its homogeneity on the thermal stability of ADI cast iron. The present work also aims to develop strategies to suppress the formation of blocky-shaped austenite in the ADI structure to maintain a homogeneous microstructure and high thermal stability.
\end{abstract}

https://doi.org/10.1007/s11661-021-06214-8

(C) The Author(s) 2021

\section{INTRODUCTION}

Austempered ductile iron (ADI) is a modern casting alloy with very good mechanical and functional properties. Due to its production cost, weight saving, and favorable strength indices related to its density, it can be successfully used for the production of modern and light cast components for operation within a wide temperature range. ${ }^{1-4]}$ From the viewpoint of material selection, ADI is, therefore, the most cost-effective solution in many applications, including automotive and light/heavy trucks, construction, railroads, agriculture, and mining equipment. ${ }^{[5-7]}$ ADI belongs to the group of high-quality ductile iron that is subjected to heat treatment, i.e., austenitization and austempering. The process of shaping the structure and properties of ADI cast iron has been known from the world literature for several decades. This applies to issues related to the numerical simulation, ${ }^{[8-10]}$ kinetics of the austenitizing

M. GÓRNY, E. TYRAŁA, and M. KAWALEC are with the Faculty of Foundry Engineering, Department of Cast Alloys and Composites Engineering, AGH University of Science and Technology, Reymonta St. 23, 30-059 Krakow, Poland. Contact email: mgorny@agh.edu.pl Ł. GONDEK is with the Faculty of Physics and Applied Computer Science, Department of Solid State Physics, AGH University of Science and Technology, Mickiewicza Av. 30, 30059 Krakow, Poland. G. ANGELLA is with the Research Institute CNR-ICMATE, via R. Cozzi 53, 20125 Milan, Italy

Manuscript submitted October 11, 2020; accepted February 19 , 2021.

Article published online March 21, 2021 and austempering processes, ${ }^{[4-8,11,12]}$ effect of alloying elements, ${ }^{[12-15]}$ structure formation, ${ }^{[11,12,16-19]}$ mechanical and fatigue properties, ${ }^{[20-23]}$ machinability, ${ }^{[24]}$ and other applications. ${ }^{[25]}$

The structural homogeneity and thermal stability affect the behavior of the material when subjected to static and dynamic loads within a wide temperature range (from extremely low to very high values). The structure of ADI cast iron can be in a metastable state, which can eventually contribute to a decrease in safety indicators and an increase in the risk of damage to the cast components during operation. As for other materials, the property variation of $\mathrm{ADI}$ at temperatures from cryogenic to elevated is influenced by its chemical composition and initial microstructure, which are, in turn, controlled by the manufacturing route and postmanufacturing treatment (e.g., heat treatment). In the literature, ${ }^{[24-35]}$ one can find information regarding the thermal stability behavior of ADI from a practical point of view. In general, it can be said that, in terms of mechanical properties, its ductility and impact strength decrease significantly and the ausferrite is converted to a bainite-type structure when ADI is held at elevated temperatures for long periods of time. On the other hand, supercooling ADI cast iron to negative temperature values can transform the austenite into martensite. The stability of ausferrite is limited by the carbon diffusion and iron carbide nucleation, which depend on the chemical composition and heat treatment procedure. As reported in Reference 36, alloying elements, such as 
$\mathrm{Ni}-\mathrm{Cu}-\mathrm{Mo}$, conferred a high thermal stability to the ausferrite microstructure; the high-carbon austenite began to decompose at higher temperatures as compared to unalloyed iron. Once the austenite is fully saturated during the austempering stage, the carbon must precipitate out of the high-carbon austenite in order to allow additional ferrite to form. Thus, the rate of microstructure decomposition can be reduced by decreasing the carbon diffusion (e.g., by increasing the carbon concentration in the austenite) or by increasing the activation energy for the nucleation of the iron carbides. The microstructure of ADIs is usually carbide free; this is the result of the high silicon level, which retards the precipitation of the cementite from the austenite. This also results in the low solid solubility in the cementite crystal structure. Also, because carbon is trapped at those twins and dislocations in the vicinity of the ferrite-austenite interface during the austempering process (as reported in References 29 and 30), this prevents the decarburization of the supersaturated ferrite platelets and, therefore, alters the carbide precipitation sequence during low-temperature bainite formation and even during its tempering processes. ${ }^{[31-33]}$

The aforementioned literature data related to structure homogeneity and thermal stability mainly refer to ADI cast iron that is heat treated at different austempering conditions and tested within a range of up to 500 ${ }^{\circ} \mathrm{C}$, while there are limited data related to the ADI cast iron behavior both attained at different austenitization temperatures and when subjected to subzero working temperatures. In addition to this, there is a lack of data linking the parameters of the crystal lattices that are determined on the basis of X-ray diffraction (XRD) studies with the structural homogeneity and thermal stability of ADI. The present research aims to enrich the knowledge of the behavior of ADI cast iron within a temperature range of $-260{ }^{\circ} \mathrm{C}$ to $+450{ }^{\circ} \mathrm{C}$ in terms of structural changes and those parameters that are related to XRD tests, which provide information that is related to the phase participation, lattice parameters, and stresses in the microstructure as well as with an expansion of the crystal lattice. The test results also consider the variable conditions of heat treatment that indicate its key role in shaping the homogeneity and thermal stability of ADI cast iron.

\section{EXPERIMENTAL}

The experimental melts were prepared in a $15-\mathrm{kg}$-capacity crucible using an electrical induction furnace of an intermediate frequency. The furnace charge consisted of Sorelmetal (high-purity pig iron: 4.46 pct C, 0.132 pct $\mathrm{Si}, 0.01$ pet Mn, 0.006 pct $\mathrm{S}, 0.02$ pct $\mathrm{P}$ ), technically pure silica, Fe-Mn, steel scrap, copper, and nickel. After being melted at $1490{ }^{\circ} \mathrm{C}$, the liquid metal was held for 2 minutes followed by spheroidization and inoculation operations using a bell method. An Fe-Si-Mg (6 pct Mg) foundry alloy was used for spheroidization, while Foundrysil ( 73 to 78 pet $\mathrm{Si}, 0.75$ to 1.25 pet $\mathrm{Ca}, 0.75$ to $1.25 \mathrm{pct} \mathrm{Ba}, 0.75$ to $1.25 \mathrm{pct} \mathrm{Al}$, bal $\mathrm{Fe}$ ) was used for inoculation purposes. The cast iron was poured at 1400 ${ }^{\circ} \mathrm{C}$ into Y-block ingots $(25 \mathrm{~mm})$ following the ASTM A 536-84(2019)el standard.

The heat treatments for the ADI production consisted of the following: (a) austenitizing in a silite furnace at temperatures of $850{ }^{\circ} \mathrm{C}, 875^{\circ} \mathrm{C}$, and $925^{\circ} \mathrm{C}$ for 2 hours; (b) austempering in a salt bath of $\mathrm{NaNO}_{2}-\mathrm{KNO}_{3}$ at 250 ${ }^{\circ} \mathrm{C}, 310{ }^{\circ} \mathrm{C}$, and $380{ }^{\circ} \mathrm{C}$ for $4.5,3$, and 1 hours, respectively; and (c) air cooling to room temperature.

The chemical composition tests of the experimental ductile irons were carried out using a SPECTRAMAXx emission spectrometer with spark excitation.

The XRD studies were made by means of an Empyrean PANalytical powder diffractometer employing Bragg-Brentano geometry. The incident beam configuration was as follows: $\mathrm{Cu}$ Long Fine Focus $\mathrm{X}$-ray tube (operating at $40 \mathrm{kV}$ and $40 \mathrm{~mA}, K_{\alpha}$ line $\lambda=$ $1.54051 \AA$ ), Ni filter for $K_{\beta}$ extraction, $0.04 \mathrm{rad}$ Soller collimator, divergence slit $(1 / 4 \mathrm{deg})$, and antiscatter slit $(1 / 2 \mathrm{deg})$. The diffracted beam configuration for the X'Celerator RTMS detector was antiscatter slit (3.9 $\mathrm{mm})$, Soller collimator ( $0.017 \mathrm{rad})$, and curved graphite monochromator. The range of the $2 \theta$ angles was set to 20 to $100 \mathrm{deg}$ with step size of $0.033 \mathrm{deg}$ and acquisition time 50 seconds per step for low- and high-temperature measurements. The positions and profiles of the observed lines were calibrated using an $\mathrm{LaB}_{6}$ standard sample. For the low-temperature studies ( 15 to $300 \mathrm{~K}$ ), an Oxford Instruments PheniX closed-cycle helium refrigerator was used. The displacement of the sample position due to the thermal expansion of the setup was automatically corrected thanks to calibration measurements involving high-purity W (99.9999 pct) powder. On the other hand, the high-temperature studies were performed using an Anton Paar HTK 1200N chamber. The measurements were made under an $\operatorname{Ar}$ (99.9999 pct) flow. The thermal sample displacements were corrected automatically. For nonambient studies, the measuring procedure was as follows: the temperature step was 10 ${ }^{\circ} \mathrm{C}$ with a ramp of $1{ }^{\circ} \mathrm{C} / \mathrm{min}$; then, a stabilization time of 10 minutes was applied. Each pattern was collected for 20 minutes. All of the collected diffraction patterns were refined with FullProf software based on the Rietveld method. ${ }^{[36]}$ In addition, a JEOL* JSM-5500LV scanning

*JEOL is a trademark of JEOL, Tokyo.

electron microscope (SEM) was used for the metallographic examinations.

\section{RESULTS AND DISCUSSION}

\section{A. Chemical Composition and XRD Analysis}

The results of the chemical composition of the experimental ADI castings are shown in Table I.

The analyzed ADIs contain copper and nickel, which are usually used in ADI cast iron to attain a pearlitic matrix of the base iron and increase the hardenability during the austempering process. The copper content 
Table I. Chemical Composition of ADI Castings

\begin{tabular}{lccccccc}
\hline Element & $\mathrm{C}$ & $\mathrm{Si}$ & $\mathrm{Mn}$ & $\mathrm{P}$ & $\mathrm{S}$ & $\mathrm{Ni}$ & $\mathrm{Cu}$ \\
\hline Wt Pct & 3.46 & 2.37 & 0.29 & 0.02 & 0.01 & 1.10 & 0.84 \\
\hline
\end{tabular}

does not exceed the recommended level in order to prevent the formation of highly dispersed $\mathrm{Mg}_{2} \mathrm{Cu}^{[37]}$ and pure copper precipitates. ${ }^{[38]}$ In addition to this, the $\mathrm{Cu}$ increases the fraction of the austenite in the ADI microstructure and suppresses the carbide formation in the lower ausferrite. ${ }^{39,40]}$ Copper and nickel also increase the maximum wall thickness that can be successfully austempered during heat treatment. These elements segregate close to the graphite regions; their distribution practically remains unchanged even after long heat treatment. The manganese was kept below the content that is recommended in the literature (i.e., 0.3). ${ }^{[6]}$ Manganese can be both a beneficial and harmful element. In castings with wall thicknesses $>20 \mathrm{~mm}$, manganese segregates toward the cell boundaries; this contributes to a decrease in the machinability as well as structure inhomogeneities. On the other hand, manganese promotes the formation of pearlite under as-cast conditions; it also strongly increases the hardenability and retards the austempering reaction. ${ }^{[41]}$

The chemical composition of the ADI used in this work ensures the attainment of high-strength ADI cast iron with a lower ausferrite as well as ADI cast iron with an upper ausferrite with excellent dynamic properties (e.g., high impact strength).

The collected XRD patterns are presented in Figures 1(a) through (c). The standard Rietveld analysis was used to calculate the structural parameters and weight fractions of the observed ADI's constituting phases. The correlation between the ferrite/austenite content and the austenitizing and austempering temperatures is shown in Figure 1(d). The observed reflections are denoted using Miller indices for the high-carbon austenite $(\gamma-\mathrm{Fe})$ and ferrite $(\alpha-\mathrm{Fe})$. Additionally, the 002 reflection of graphite was observed.

From Figure 1(d), it follows that the high-carbon austenite increases as the austempering temperature increases (irrespective of the austenitizing conditions). The highest ferrite fraction and lowest austenite fraction were obtained at the lowest austenitizing $\left(850{ }^{\circ} \mathrm{C}\right)$ and austempering $\left(250{ }^{\circ} \mathrm{C}\right)$ temperatures (which amounted to 86.5 and $13.5 \mathrm{pct}$, respectively). In turn, the smallest ferrite fraction and largest austenite fraction were obtained at the highest austenitizing $\left(925^{\circ} \mathrm{C}\right)$ and austempering $\left(380{ }^{\circ} \mathrm{C}\right)$ temperatures (which amounted to 47.9 and 52.1 pct, respectively). From Figure 1(d), it can be seen that the austenitization and austempering temperatures have a great impact on the final proportion of the metal matrix components. The lattice parameters of the austenite and ferrite determined by XRD are presented in Figure 2.

In ADIs, the best combination of plasticity and toughness, which are the most desirable properties required in applications worldwide (such as in automotive parts, construction, agriculture, and railroad components), is attained when the austenite fraction and lattice parameter resulting from the carbon content in the austenite are at their maximum levels. As shown in Figure 2, this coincides with the second segment of the isothermal transformation period (recognized as the "optimum isothermal transformation period") and is also strongly dependent on the first segment (i.e., the austenitizing stage). This XRD study showed that the austenite lattice parameter increases with rising austempering temperatures, reaching its maximum value at a temperature of $310^{\circ} \mathrm{C}$. An austempering temperature at $380{ }^{\circ} \mathrm{C}$ did not cause the lattice parameter of the austenite to grow. It is well known that the carbon content is directly proportional to the lattice parameter of the austenite, which results from the following relationship ${ }^{[42]}$ :

$$
a \gamma=0.3555+0.0045 \mathrm{C} \gamma-0.00019 \mathrm{Si}
$$

where $a \gamma$ is the austenite lattice parameter (nanometers) and $C \gamma$ is the carbon content in the austenite (wt pct), and $\mathrm{Si}$ is the silicon content (wt pct).

The XRD tests also show that increasing the austenitizing temperature to a level of $925^{\circ} \mathrm{C}$ reduces the austenite lattice parameter in the ADI cast iron, i.e., in accordance with Eq. [1]'s final carbon content in the austenite. This effect is related to the formation of unfavorable blocky austenite regions, the presence of which is characteristic of high austenitizing temperatures. Generally, it can be concluded that the lattice parameters of the austenite and ferrite are closely related to the carbon content and the phase fraction in the microstructure, which are a function of the austenitization and austempering temperatures as well as the isothermal annealing time for a given chemical composition of ADI cast iron. The microstructure of ADIs is composed of graphite nodules, bainitic ferrite plates**

\footnotetext{
**The use of the term "bainitic ferrite" emphasizes the fact that it is saturated with carbon (in contrast to the ferrite that is found in cast iron and cast steel, where the carbon content is negligibly low).
}

that are slightly enriched in carbon (with a high density of dislocations), and high-carbon austenite. During the austempering transformation, only a small fraction of the carbon is conserved in the ferrite; the rest remains in the austenite (which can contain up to 2 pct).

Figure 2 also gives us insight into the lattice parameter of the ferrite. In the case of the lowest applied austempering temperature (i.e., $250{ }^{\circ} \mathrm{C}$ ), the diffusion process is at its slowest, which leads to the low values of the lattice parameters of the bainitic ferrite. The low fraction of the austenite formed in ADI cast iron at this austempering temperature as well as the slow diffusion processes makes it difficult to transport the carbon from the bainitic ferrite to the austenite, which results in a low lattice parameter of the austenite (Figure 2(a)). When an austenitization temperature of $850{ }^{\circ} \mathrm{C}$ and an austempering temperature of $310{ }^{\circ} \mathrm{C}$ were used, the highest lattice parameter was obtained. This effect can be explained by the faster carbon diffusion as compared 


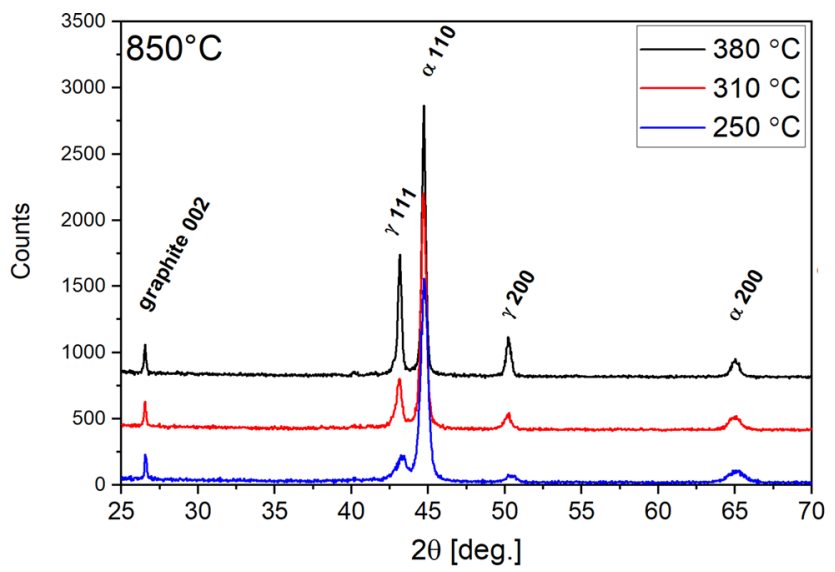

(a)

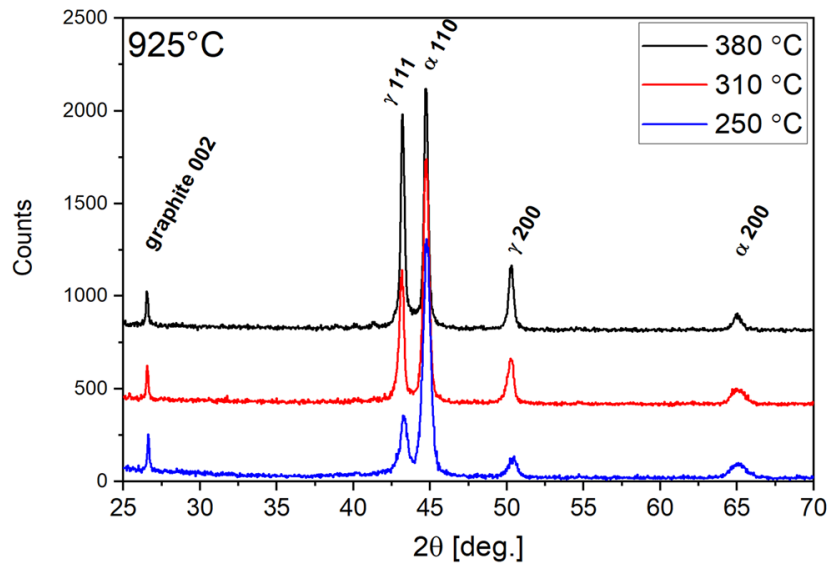

(c)

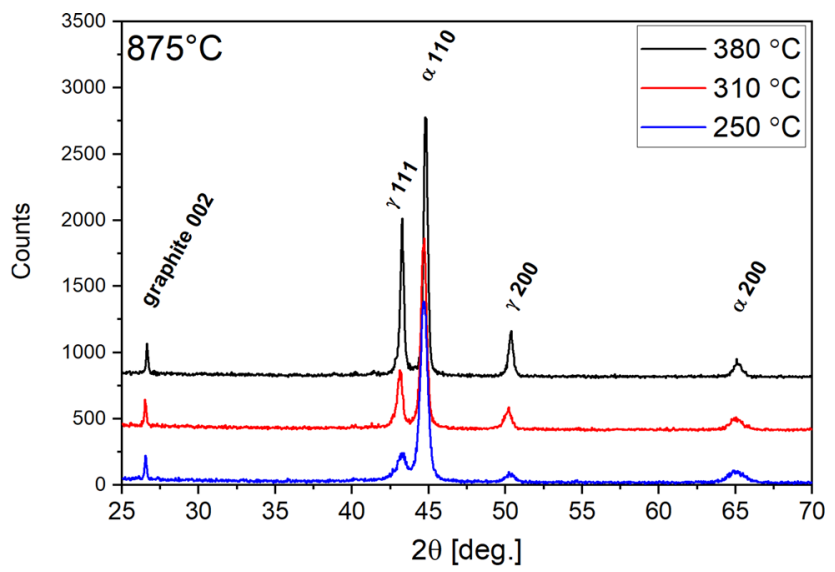

(b)

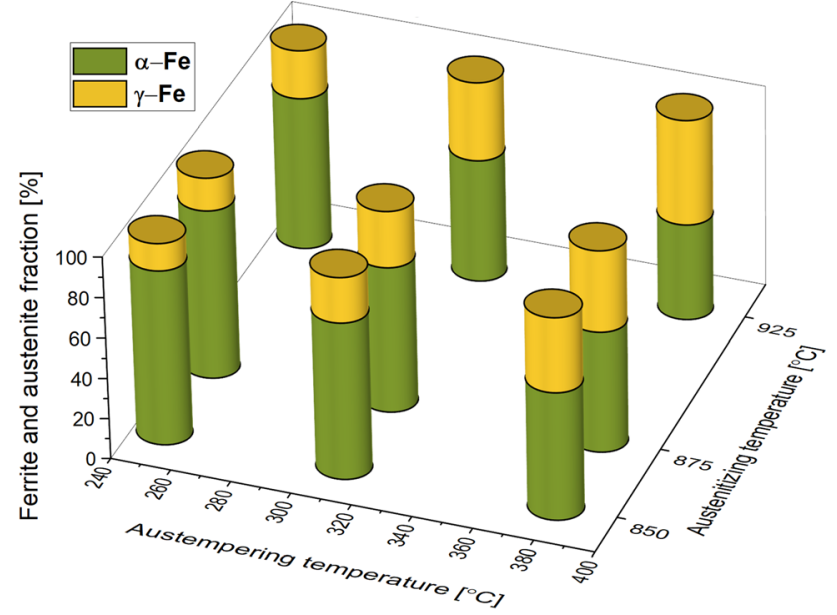

(d)

Fig. 1- (a) through $(c)$ XRD patterns of ADI attained under different heat treatment conditions. (d) Bainitic ferrite and high-carbon austenite weight fractions in the metallic matrix as a function of austenitizing and austempering temperatures.

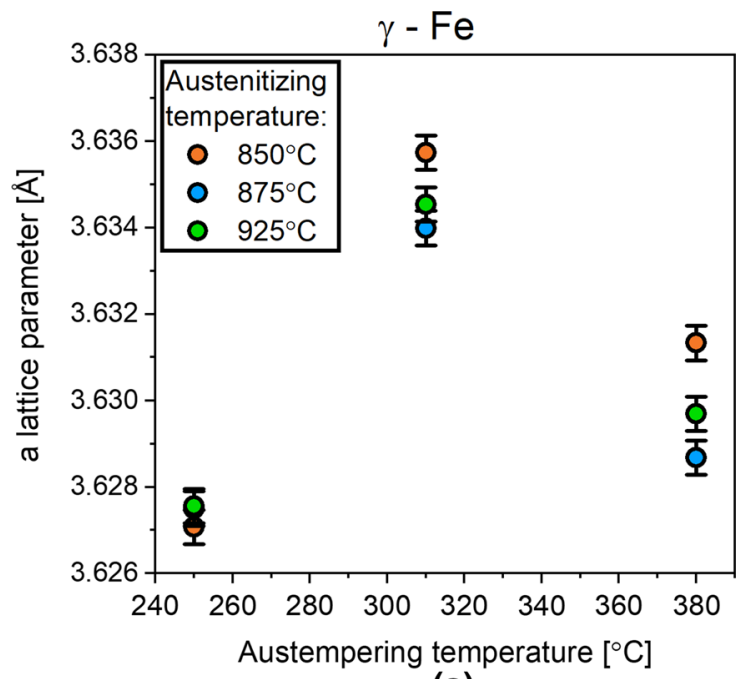

(a)

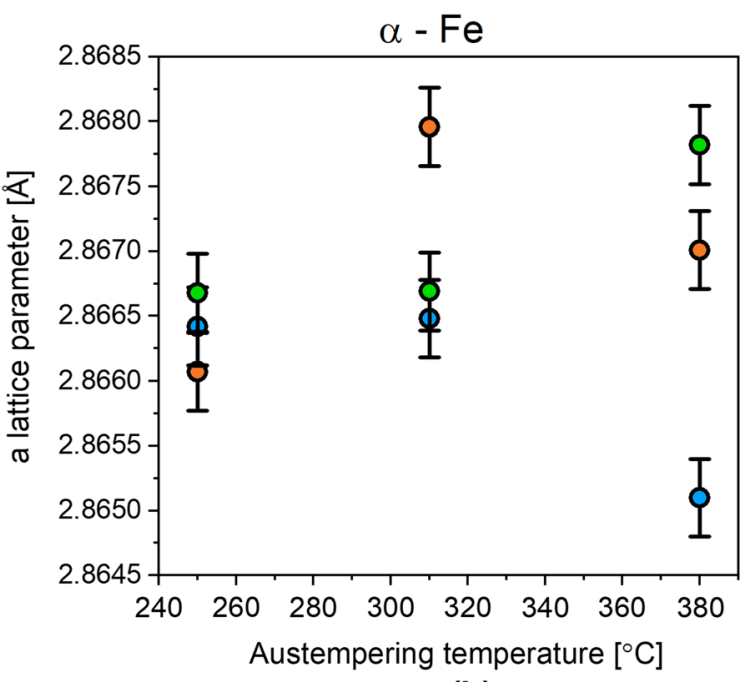

(b)

Fig. 2-Lattice parameters of $(a)$ austenite and $(b)$ ferrite as a function of austenitizing and austempering temperatures. 
to the isothermal transformation conditions at $250^{\circ} \mathrm{C}$ as well as the nearly double austenite fraction $(f \gamma=22.4$ pct). For the heat treatment conditions (i.e., austenitizing temperatures of $875{ }^{\circ} \mathrm{C}$ and $925{ }^{\circ} \mathrm{C}$ and an austempering temperature of $310^{\circ} \mathrm{C}$ ), the value of the lattice parameter of the ferrite decreased. This should be equated with a much greater austenite fraction in the microstructure, which proved that the accelerated diffusive carbon transport occurred at a greater extent. Due to the similar ferrite and austenite fractions, their lattice parameters are also similar. For the highest values of the austenitization $\left(925{ }^{\circ} \mathrm{C}\right)$ and austempering $\left(380{ }^{\circ} \mathrm{C}\right)$ temperatures, the ferrite lattice parameter increased as compared to the value obtained for an austempering temperature of $310{ }^{\circ} \mathrm{C}$. This is the effect of its high heterogeneity and the presence of martensite in the ADI cast iron microstructure (which is located in large blocky areas (Figure 5)). The negative effect of such an inhomogeneous structure is the low lattice parameter of the austenite as compared to the value obtained at an austempering temperature of $310^{\circ} \mathrm{C}$.

The lattice strain caused by the phase transformation as a function of the austenitization and austempering temperatures is illustrated in Figure 3. In general, the lattice strain is defined as the degree of the atoms' departures from their nominal positions within the crystal unit cell. Usually, this can be considered to be the ratio of $\mathrm{d} L$ to $L$, where $L$ is the lattice parameter and $\mathrm{d} L$ is the change due to the defects. The discussed lattice strain is related to the static defects of the crystal, such as vacancies, interstitial and Frenkel defects, dislocations, grain boundaries, and stacking faults. These defects may originate from a number of factors such as undergoing stresses resulting in plastic deformations or the thermal history of the alloy (e.g., the cooling rate

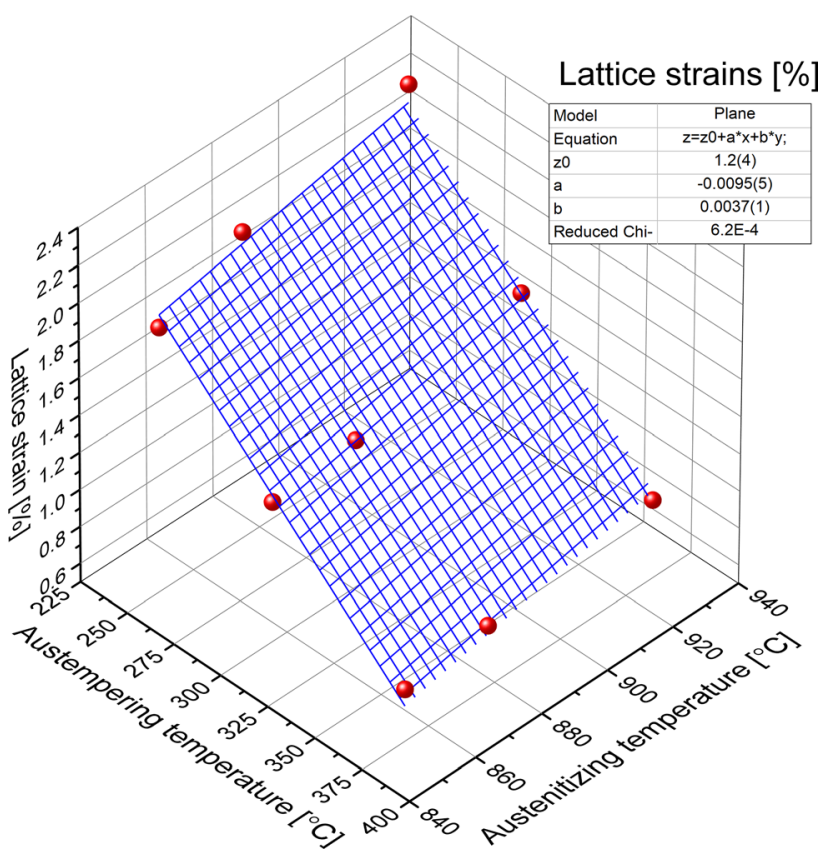

Fig. 3-Influence of austenitization and austempering temperatures on the lattice strain in ferrite. from the liquid metal, annealing temperature, and time). In XRD, the lattice strain broadens the reflections, which can be analyzed in terms of the Williamson-Hall method. ${ }^{[43]}$ The lattice strain in ferrite is proportional to the austenitizing temperature and inversely proportional to the austempering temperature; this can be represented by a plane with adjusted $R^{2}=0.982$. The lattice strain in ferrite is mainly caused by interstitial carbon. The highest value of lattice strain was obtained for the highest applied austenitization temperature $\left(925^{\circ} \mathrm{C}\right)$ and the lowest austempering temperature $\left(250{ }^{\circ} \mathrm{C}\right)$. This behavior can be explained by the interaction of supersaturated carbon content in the ferrite and austenite and also by the presence of the blocky austenite in which martensite can be formed. In the austenitization process, the role of carbon is very important. An increase in the austenitizing temperature $\left(T_{\gamma}\right)$ causes the carbon content in the austenite to increase before the austempering process according to equation. ${ }^{[14]}$.

$$
C_{\gamma}^{\circ}=T_{\gamma} / 420-0.17(\text { pct Si })-0.95
$$

A higher austenitizing temperature will lead to a higher carbon concentration in the austenite before the austempering process. As will be shown later, this does not mean that the final carbon content in the austenite will be higher after the austempering process (Figure 7). This, in turn, slows the nucleation and growth process of the ferrite platelets. Increasing the austenitizing temperature decreases the driving forces for the austempering reaction and increases the austempering time needed to obtain high-carbon austenite (Figure 4(a)). The nucleation process of the ferrite platelets affects the final fraction, the morphology of the high-carbon austenite, and the lattice strain. A higher austenitization temperature decreases the number of ferrite plates and will lead to a greater heterogeneity of the metallic matrix by creating a higher fraction of the blocky type of high-carbon austenite and the greater thermodynamic instability of the blocky austenite that can undergo partial transformation into martensite (as will be shown later).

The driving force for the austempering reaction also depends on the austempering temperature. Decreasing the austempering temperature (for a given austenitizing temperature) increases the driving forces for the austempering reaction (Figure 4(b)).

This leads to a higher ferrite fraction and a higher number of ferrite plates (with smaller thicknesses). The ferrite plates created during the austempering process are in a carbon-supersaturated state in the ADI (as reported in Reference 45). The degree of the saturation of the bainitic ferrite with carbon (and, thus, its lattice strain) increases with increases in the degree of supercooling relative to the austenitizing temperature, i.e., with decreases in the austempering temperature (Figure 3).

\section{B. Microstructure Evolution}

Figure 5 shows micrographs of the microstructures exhibited in the ADI samples. 


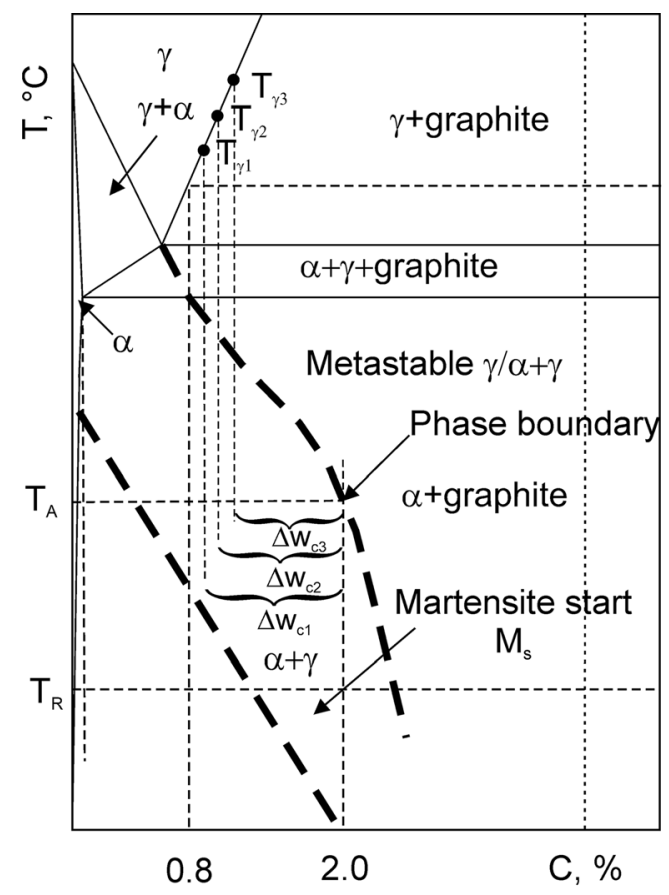

(a)

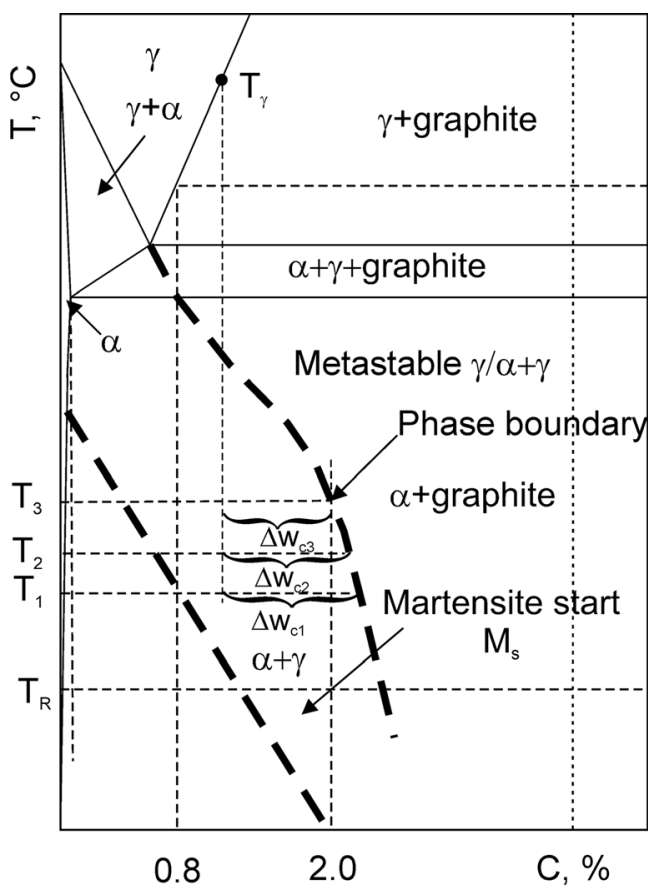

(b)

Fig. 4-Schematic temperature-carbon concentration section in the $\mathrm{Fe}-\mathrm{C}$ phase diagram: $(a)$ constant austempering temperature and $(b)$ constant austenitizing temperature. Driving force for austempering transformation: $\Delta \mathrm{wc} 3>\Delta \mathrm{wc} 2>\Delta \mathrm{wc}$. Adapted with permission from Ref. [44].
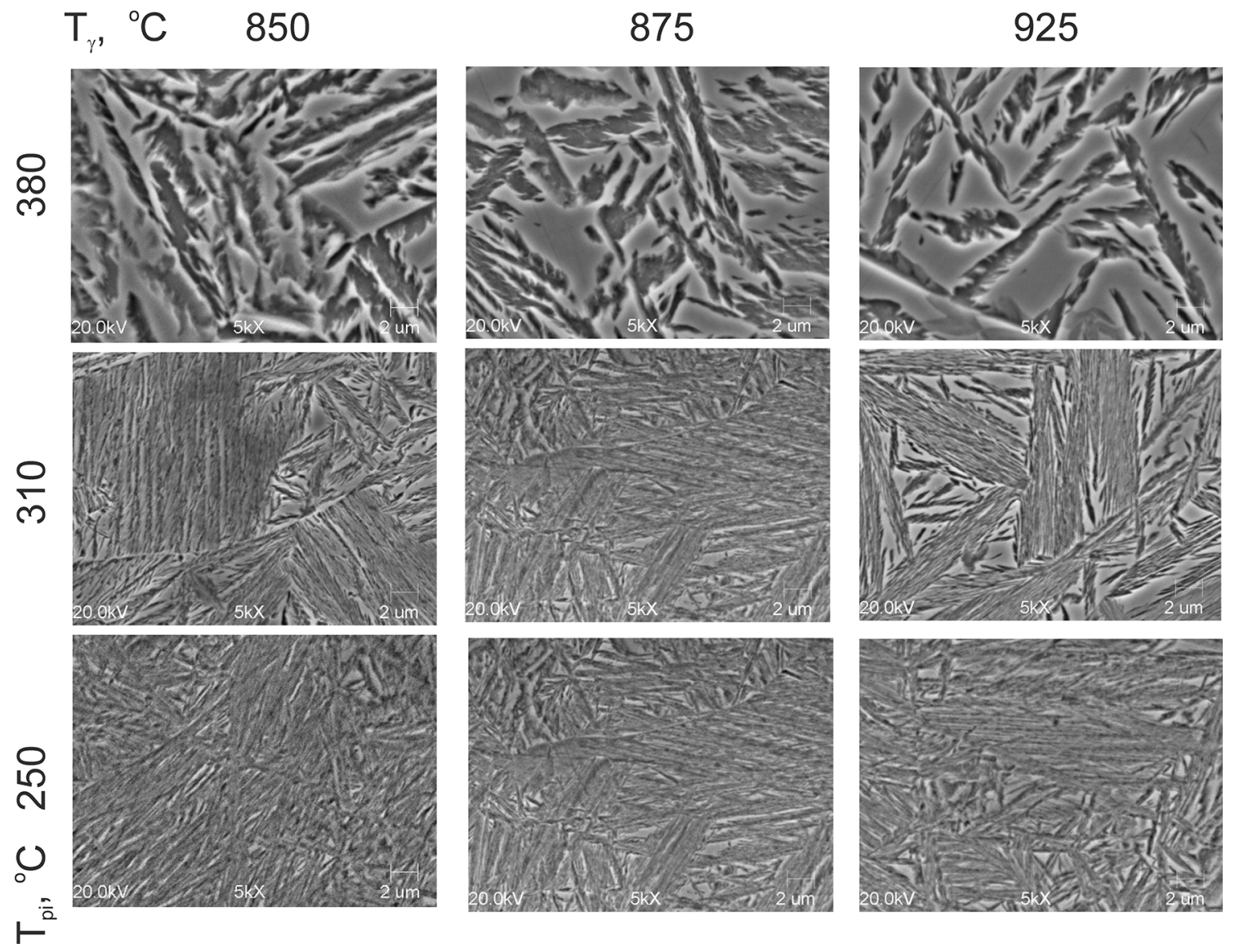

Fig. 5-SEM microstructure of tested ADI cast iron as a function of austenitization $\left(\mathrm{T}_{\gamma}\right)$ and austempering (Tpi) temperatures. 
An analysis of the ADI microstructure shows that the heat treatment (i.e., the austenitizing and austempering temperatures) has a meaningful influence on the final ADI microstructure. From Figure 5, it follows that an increase in the austenitizing temperature reduces the number of ferrite plates and increases their thickness in all cases for a given austempering temperature. From Reference 46, it follows that a smaller number of ferrite plates results in the formation of the so-called "blocky" high-carbon austenite, which is not involved in the austempering transformation. This phenomenon is clearly visible, especially at an austempering temperature of $380{ }^{\circ} \mathrm{C}$. The high austenitization temperature may lead to the local inhomogeneity of the ausferrite, which manifests itself as the occurrence of martensite in these areas. A high austempering temperature is used when the aim is to obtain high dynamic properties (i.e., high impact strength and plasticity). The presence of martensite (estimated at a level of 5 pct) in the sample that was austenitized at $925{ }^{\circ} \mathrm{C}$ is the result of a too-short austempering time. In the other cases, martensite was not detected in the microstructure of the ADI cast iron. It is worth emphasizing that, in the cases of lowering the austempering temperature to a level of 310 ${ }^{\circ} \mathrm{C}$ and even further (to $250{ }^{\circ} \mathrm{C}$ ), the fraction of the blocky austenite significantly decreases to trace levels (Figure 5). In the case of the lower ausferrite obtained at a low austempering temperature $\left(250{ }^{\circ} \mathrm{C}\right)$, the highest ferrite fraction and the greatest number of ferrite plates were obtained, which resulted in the highest homogeneity of the microstructure without visible areas containing the blocky austenite. As the austempering and austenitization temperatures change, the bainitic ferrite morphology also changes. At higher austempering temperatures, the thicknesses of these plates are larger and the distances between them are greater. Moreover, in the microstructure of the sample that was austenitized at a temperature of $925{ }^{\circ} \mathrm{C}$ and austempered at a temperature of $310^{\circ} \mathrm{C}$, it can be noticed that the ferrite plates are arranged in the form of packages. The homogeneity of the ausferritic matrix is visible regardless of the austenitizing temperature (in contrast to the upper ausferrite obtained at $380^{\circ} \mathrm{C}$ ).

\section{Thermal Stability}

The issue of thermal stability is of great practical importance, as it significantly affects the conditions in which cast components made of high-quality ADI cast iron can be used. As part of this study, the changes in the parameters resulting from the XRD tests were analyzed, which provide information related to the phase participation, lattice parameters, stresses in the microstructure, and deformation of the crystal lattice. Figure 6 shows the XRD patterns as a function of temperature for ADI attained under two different heat treatment conditions.

In Figure 6, the XRD patterns collected for the investigated specimens are presented. The high- and low-temperature patterns were joined together into one plot, while substantially different measuring conditions (sample environments) resulted in some discontinuities.
Nonetheless, presenting data in this way makes it much easier for a head-to-head comparison.

At first, the intensities of the $\gamma$-phase reflections (roughly at 43.5 and $50.5 \mathrm{deg}$ of $2 \theta$ ) decrease for both samples below room temperature. However, for the 850/ 380 sample (Figure 6(a)), the decrease takes place below - $130{ }^{\circ} \mathrm{C}$, while for $925 / 380$, a similar process takes place just below $-30{ }^{\circ} \mathrm{C}$ (Figure 6(b)). The aforementioned decrease can be easily tracked by inspecting the 200 reflection of the $\gamma$ phase at $50.5 \mathrm{deg}$ of $2 \theta$. Moreover, the drop of the intensity of the 200 reflection is much higher in the 925/380 sample. These observations will be reflected in the results of the Rietveld analysis of the collected data.

For higher temperatures (namely, within a range of 25 ${ }^{\circ} \mathrm{C}$ to $200{ }^{\circ} \mathrm{C}$ ), no significant changes can be noticed. Above this range, the reflections of the $\gamma$ phase deteriorate. For the $850 / 380$ sample, the intensity of the 200 reflection at $50.5 \mathrm{deg}$ of $2 \theta$ diminishes above $275^{\circ} \mathrm{C}$ (to dissolve completely at $435^{\circ} \mathrm{C}$ ). For the other discussed sample $(925 / 380)$, a similar scenario was observed. The respective temperatures are lower: The start of the $\gamma$-phase deterioration can be noticed at $220^{\circ} \mathrm{C}$, while the dissolving occurs at $425^{\circ} \mathrm{C}$.

The data attained on the basis of the Rietveld method enabled an analysis of the thermal stability of ADI cast iron samples subjected to annealing or cooling in terms of changes in the lattice parameters, phase changes, dimensional expansion, and generated stresses in the crystal lattice. The results of the lattice parameters of the ADI cast iron samples obtained at different austenitizing temperatures are shown in Figure 7.

The range in which the ADI cast iron samples were tested covers extremely negative temperature values (i.e., $-260{ }^{\circ} \mathrm{C}$ ) and positive values (up to $450{ }^{\circ} \mathrm{C}$ ). During heating at around a temperature of $230{ }^{\circ} \mathrm{C}$, the ADI obtained for the higher austenitization temperature (i.e., $925{ }^{\circ} \mathrm{C}$ ) shows an increase in the ferrite fraction (Figure 8), a decrease in the lattice parameter of the ferrite, and sample shrinkage that is related to the precipitation of independently nucleating cementite $\mathrm{M}_{3} \mathrm{C}$. This effect is not visible in the ADI cast iron that was obtained at a lower austenitization temperature (i.e., $850{ }^{\circ} \mathrm{C}$ ). Therefore, it can be concluded that this is related to the tempering of the martensite present in the blocky austenite regions (as shown in Figure 5).

The effect of the tempering on the ausferrite structures is much less pronounced than for the martensite, the main reason being that the ferrite plates are less supersaturated in carbon. Martensite tempering involves the release of ADI carbides $\left(\mathrm{Fe}_{2,4} \mathrm{C}\right)$ in the cast iron structure ranging from about $230{ }^{\circ} \mathrm{C}$ to $425{ }^{\circ} \mathrm{C}$; as a result of this, the carbon content of the martensite decreases. At the same time, the diffusive transformation of the high-carbon austenite into a bainitic structure takes place. Within this temperature range, a mixture of high-carbon austenite, ferrite (slightly supersaturated with carbon), and $\varepsilon$ carbides formed. As the carbides are released from the martensite, the tetragonal degree of its lattice structure $c / a$ decreases. At the same time, Figure 7 shows that the lattice parameter of the austenite increases, which is related to the increase in its carbon 


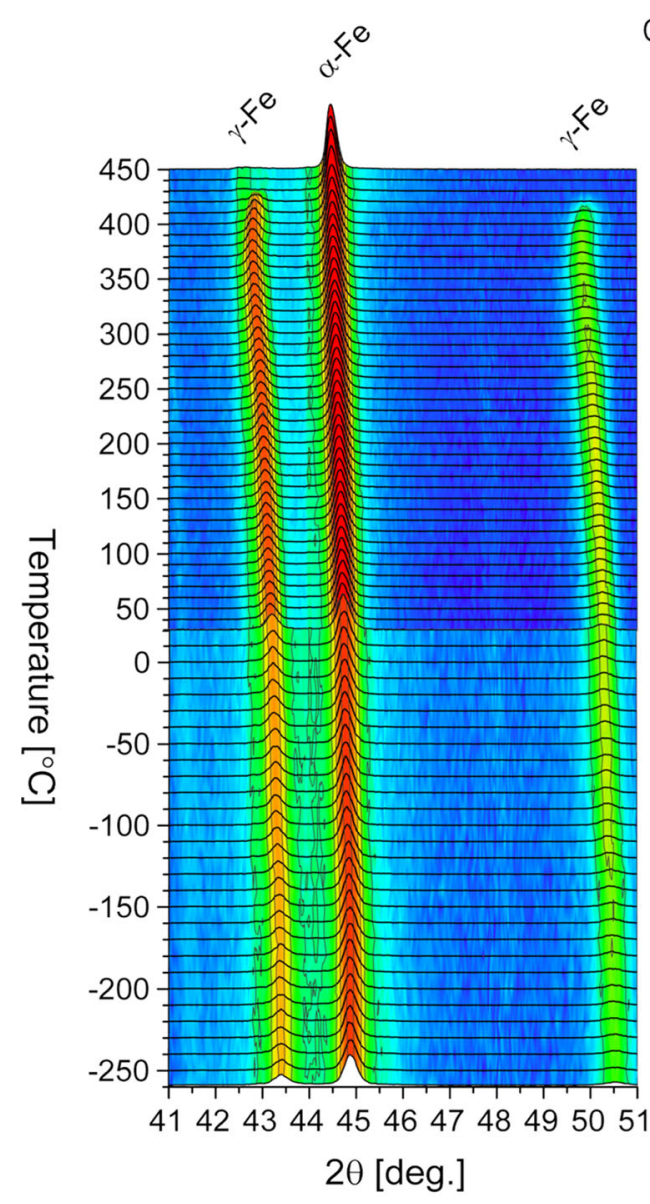

(a)

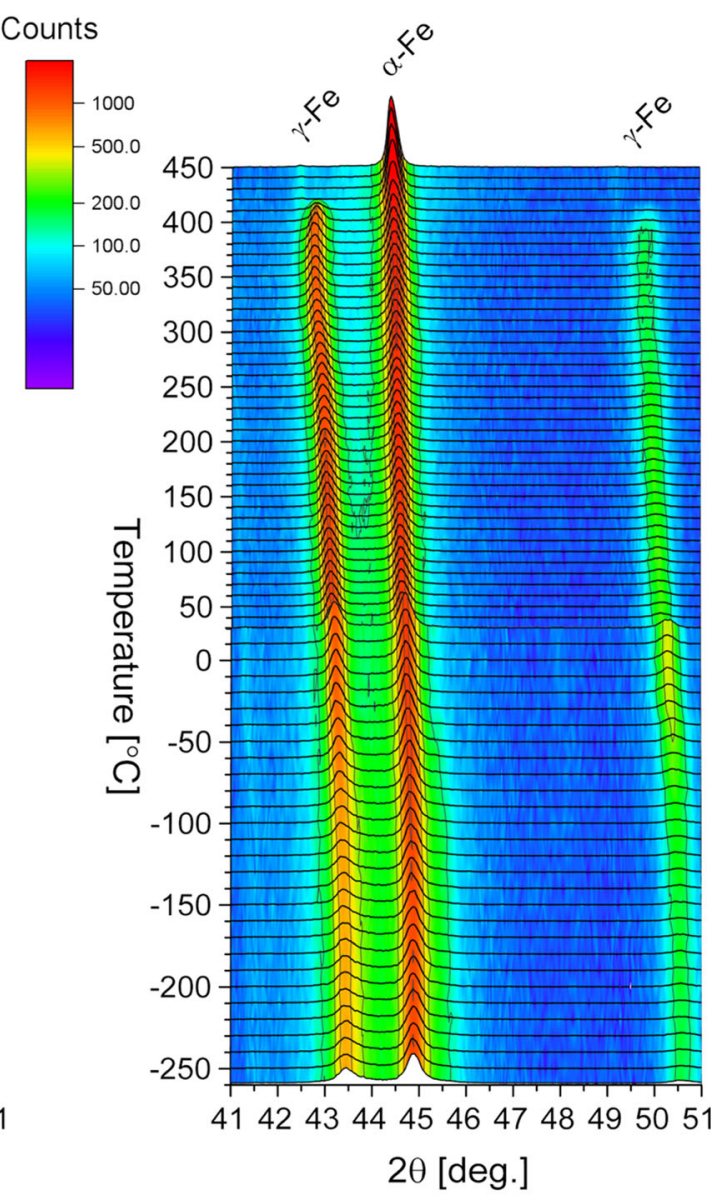

(b)

Fig. 6-XRD patterns as a function of temperature of ADI attained under two different heat treatment conditions: $(a) 850 / 380$ and $(b) 925 / 380$ $\left(850 / 380\right.$ means heat treatment conditions, i.e., austenitization at $850{ }^{\circ} \mathrm{C}$ and austempering at $\left.380{ }^{\circ} \mathrm{C}\right)$. Please note that measurements at high and low temperatures were joined together. Different measuring chambers, sample orientations, and environments result in some discontinuous behavior (which can be seen at $25^{\circ} \mathrm{C}$ ).

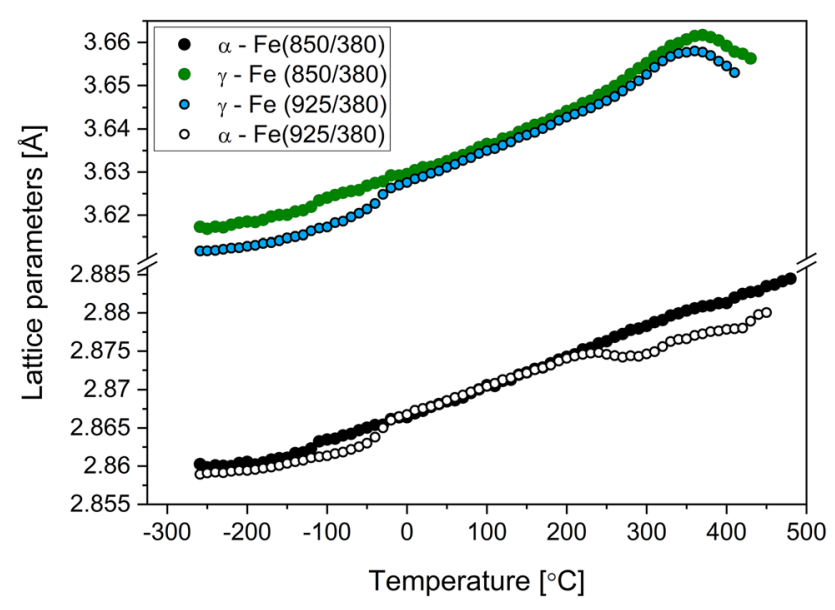

Fig. 7-Lattice parameters as a function of the temperatures of 850 / 380 and $925 / 380$ samples.

content. These processes cause a significant increase in the stresses of the austenite and ferrite crystal lattices (Figure 9) above $300{ }^{\circ} \mathrm{C}$.
A further increase in temperature causes a rapid reduction in the stresses of the ferrite lattice with the constantly increasing stresses of the austenite lattice until it decomposes into ferrite and cementite. The XRD patterns shown in Figure 6 are also reflected in Figure 7. In the case of the ADI sample austenitized at $850^{\circ} \mathrm{C}$, a proportional and continuous increase in the lattice parameters of the austenite and ferrite as a function of temperature is observed due to the lack of martensite in the structure, with no sudden changes in the proportion of the phases, i.e., the ferrite and high-carbon austenite (Figure 8(a)) and lattice stresses (Figure 9(a)). This proves that the ADI $(850 / 380)$ cast iron is more stable than the ADI $(925 / 380)$ cast iron. It should be emphasized that the decomposition of the high-carbon austenite itself occurs at a higher temperature (i.e., 435 ${ }^{\circ} \mathrm{C}$ for the $850 / 380$ sample), whereas the temperature for this is $425^{\circ} \mathrm{C}$ for the $925 / 380$ sample.

Additionally, it is worth noting that, within the entire tested temperature range, the value of the austenite lattice parameter in the ADI (850/380) cast iron is higher than in the ADI $(925 / 380)$ cast iron. This means that the higher austenitizing temperature that leads to a higher 


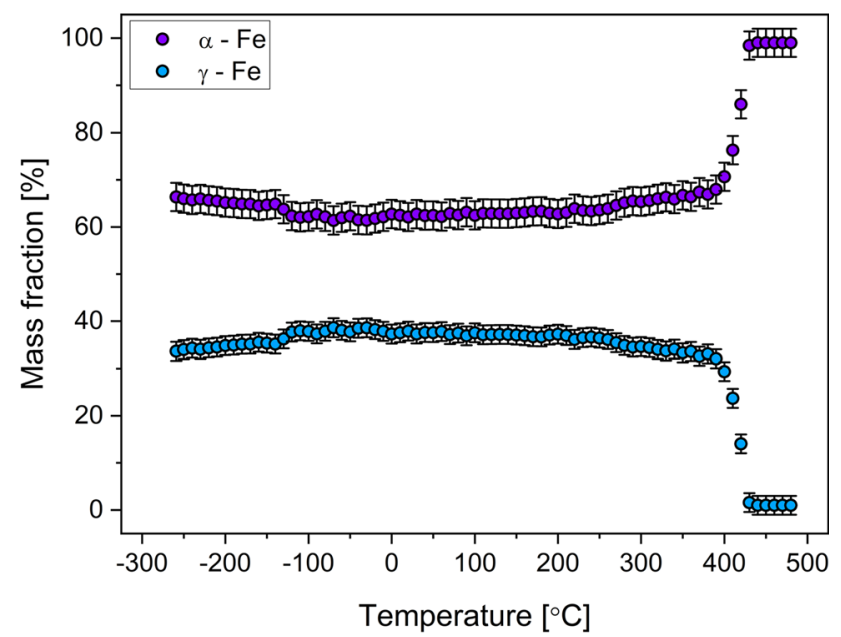

(a)

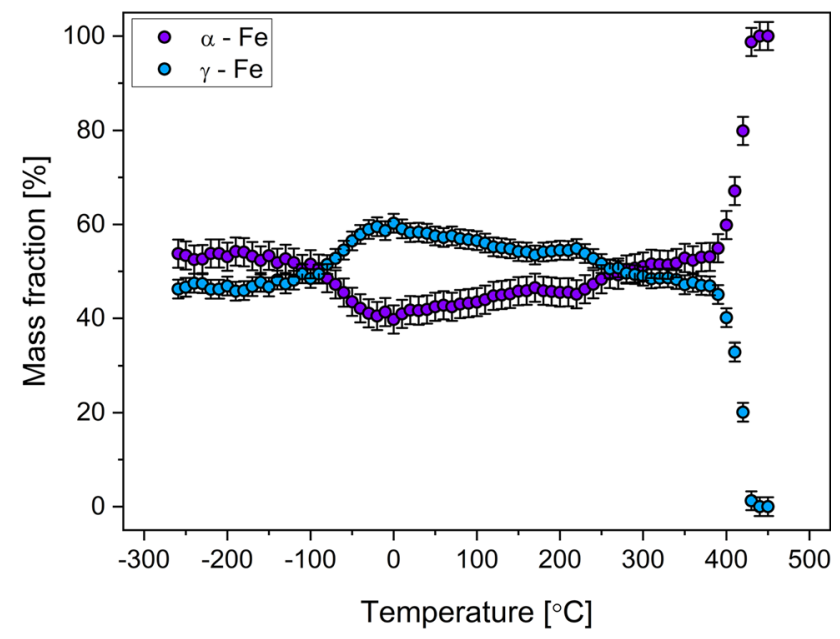

(b)

Fig. 8-Reaction of austenite and ferrite as a function of temperature: (a) 850/380 sample and (b) 925/380 sample.

carbon concentration in the austenite before the austempering process does not mean that the final value of the lattice parameter or the resulting carbon content in the austenite after the austempering process will be greater.

The range of negative temperature values undoubtedly plays an important role in the analysis of the possibility of using ADI cast components at variable temperatures. The key to this stability of the structure and properties is the homogeneity of the structure, the proportion of the phases, and the carbon content of the high-carbon austenite. Figure 7 shows that the higher austenitization temperature $\left(925{ }^{\circ} \mathrm{C}\right)$ adversely affects the durability and homogeneity of the structure during the heating and cooling of ADI cast iron. As during the heating and cooling of the ADI cast iron sample austenitized at a temperature of $850{ }^{\circ} \mathrm{C}$, a proportional and continuous decrease in the austenite and ferrite lattice parameters as a function of temperature is observed - no sudden changes in the phase fraction or lattice stresses. The case of the higher austenitization

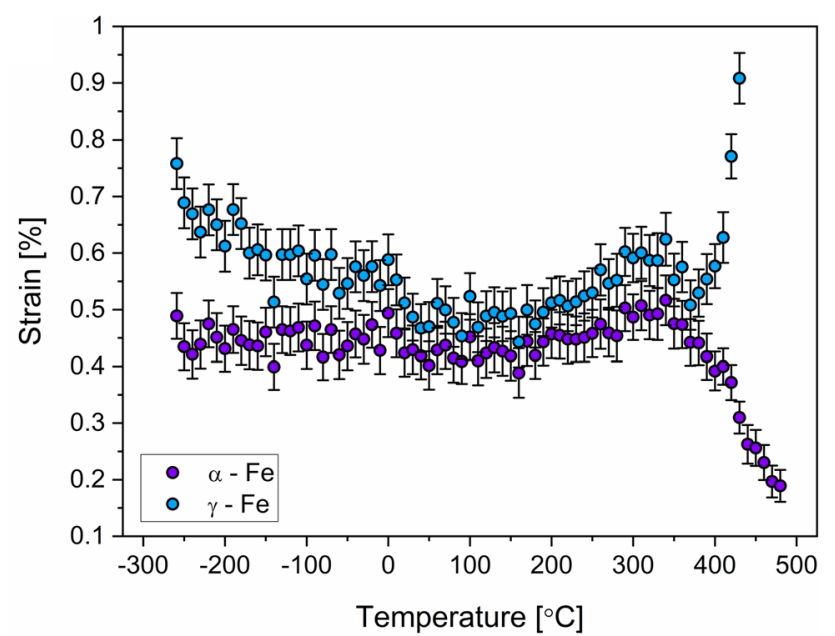

(a)

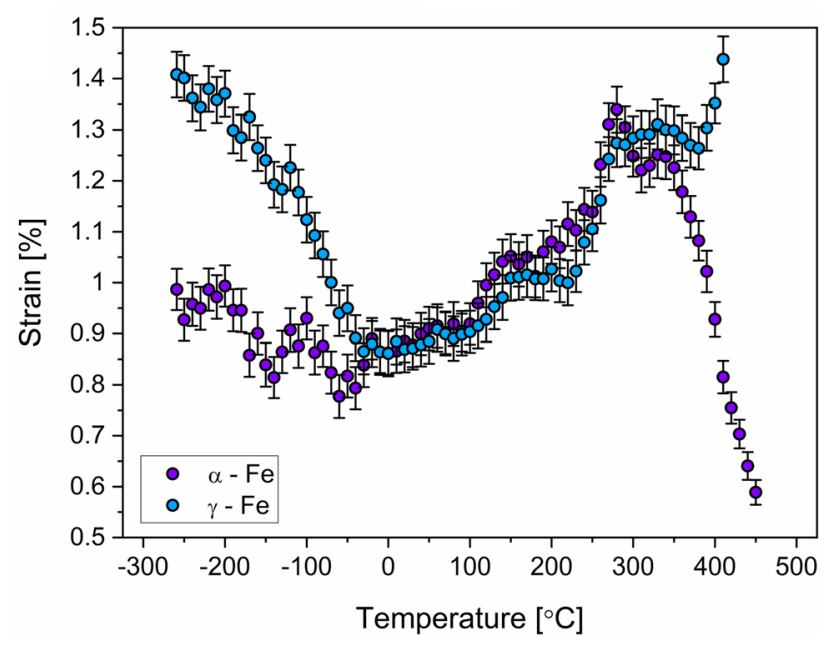

(b)

Fig. 9-Strain in austenite ferrite as a function of temperature: $(a)$ $850 / 380$ sample and (b) 925/380 sample.

temperature $\left(925^{\circ} \mathrm{C}\right)$ of the ADI cast iron caused a relatively fast decay of the unstable (blocky) austenite into the martensite starting from subcooling below -20 ${ }^{\circ} \mathrm{C}$. Subcooling to a temperature of $-20{ }^{\circ} \mathrm{C}$ or lower causes the spatially centered cubic structure to transform into a spatially centered tetragonal structure. The regular structure of the ferrite is unable to dissolve the carbon content; therefore, the carbon is precipitated in a tetragonally deformed martensite lattice. As a result, the unstable blocky austenite is converted almost entirely to martensite. This is accompanied by a sharp decrease in the lattice parameters of the austenite and ferrite, a decrease in the austenite fraction, a decrease in the expansion of both the austenite and ferrite (Figure 10), and a sudden increase in austenite stresses. The preceding effect of uncontrolled changes in the structure and volume causes the high thermal instability of heattreated ADI cast iron components, which leads to lower safety indicators and an increased risk of damage during operation. 


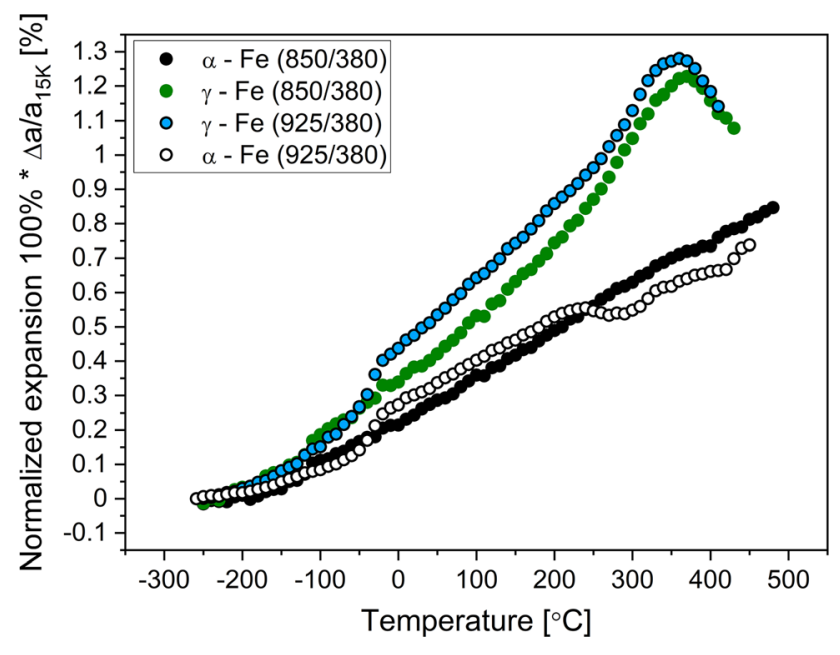

Fig. 10-Normalized expansion as a function of temperature.

\section{CONCLUSIONS}

The present study allows us to draw the following conclusions.

1. The process of obtaining a homogeneous structure that is free of austenite blocky areas strongly depends on the parameters of the heat treatment (especially the austenitizing temperature). This has a significant effect on the lattice parameters and fractions of the austenite and ferrite as well as on the strain induced in these phases of ADI cast iron.

2. A higher austenitizing temperature, which leads to a higher carbon concentration in the austenite before the austempering process, does not mean that the final austenite carbon content will be higher after the austempering process. It was shown that the lattice parameter of the austenite in the ADI cast iron obtained at the lower austenitizing temperature (850/380) has higher values (and, therefore, a higher carbon content) as compared to the ADI cast iron obtained at the higher austenitizing temperature $(925 / 380)$.

3. The lattice strain in the ferrite is proportional to the austenitizing temperature and inversely proportional to the austempering temperature and can be represented by the following plane:

$$
z=z 0+a x+b y
$$

where $z 0=1.2, a=-0.0095$, and $b=0.0037$, with a high correlation coefficient $(R=0.99)$.

4. In the case of the lower ausferrite obtained at a low austempering temperature $\left(250{ }^{\circ} \mathrm{C}\right)$, the highest ferrite fraction and the greatest number of ferrite plates were obtained, which resulted in the highest homogeneity of the microstructure without visible areas that contained blocky austenite.

5. The analysis of the thermal stability of ADI cast iron that included extremely low temperature values (i.e., $-260{ }^{\circ} \mathrm{C}$ ) and positive values (up to $450{ }^{\circ} \mathrm{C}$ ) showed that, in the case of the ADI sample austenitized at $850{ }^{\circ} \mathrm{C}$, a proportional and continuous increase in the lattice parameters of the austenite and ferrite occur as a function of temperature due to the lack of martensite in the structure. No sudden changes in the phase fraction (Figure 8(a)) or lattice stresses (Figure 9(a)) occurred.

6. The heating of ADI that contains martensite causes a tempering effect that consists of the precipitation of $\varepsilon\left(\mathrm{Fe}_{2,4} \mathrm{C}\right)$ carbides in the ADI structure within a temperature range of about $230{ }^{\circ} \mathrm{C}$ to $425^{\circ} \mathrm{C}$. At the same time, the diffusive transformation of the high-carbon austenite into a bainitic structure takes place. The effect of tempering the ausferrite structure is much less pronounced than for the martensite. The main reason for this is that the ferrite plates are less supersaturated in carbon as compared to the martensite.

7. During the cooling of ADI cast iron (austenitized at $850{ }^{\circ} \mathrm{C}$ ) within a range of negative temperature values (down to $-260{ }^{\circ} \mathrm{C}$ ), a proportional and continuous decrease in the austenite and ferrite lattice parameters as a function of temperature is observed. In addition to this, no sudden changes in the phase fraction or lattice stresses were detected. In the case of the ADI cast iron obtained at a higher austenitizing temperature $\left(925{ }^{\circ} \mathrm{C}\right)$, cooling to negative temperatures resulted in the relatively fast decomposition of the unstable (blocky) austenite into martensite starting from subcooling below $-20{ }^{\circ} \mathrm{C}$. The effect of the uncontrolled changes in the structure and volume caused the high thermal instability of the heat-treated ADI cast iron components, which can lead to a reduction in safety indicators and an increase in the risk of damage during operation.

\section{ACKNOWLEDGMENTS}

This work was supported by the Directorate General Cultural and Economic Promotion and Innovation, Italian Department of Foreign Affairs (Italy), and the Polish National Agency for Academic Exchange (PPN/BIL/2018/2/00106/U/00001).

\section{OPEN ACCESS}

This article is licensed under a Creative Commons Attribution 4.0 International License, which permits use, sharing, adaptation, distribution and reproduction in any medium or format, as long as you give appropriate credit to the original author(s) and the source, provide a link to the Creative Commons licence, and indicate if changes were made. The images or other third party material in this article are included in the article's Creative Commons licence, unless indicated otherwise in a credit line to the material. If material is not included in the article's Creative Commons licence 
and your intended use is not permitted by statutory regulation or exceeds the permitted use, you will need to obtain permission directly from the copyright holder. To view a copy of this licence, visit http://creat ivecommons.org/licenses/by/4.0/.

\section{REFERENCES}

1. M. Holtzer, M. Górny, and A. Kmita: Int. J. Global Warming, 2017, vol. 11, pp. 495-514.

2. M.M. Cisneros-Guerrer, R.E. Campos-Cambranis, M. Castro-Román, and M.J. Pérez-López: Adv. Mater. Res., 1997, vols. 4-5, pp. 415-20.

3. B.N. Olson, K.B. Moore, and G.R. Simula: AFS Trans., 2002, vol. 111 , pp. $965-82$

4. O.E. Cekic, L. Sidjanin, D. Rajnovic, and S. Balos: Met. Mater. Int., 2014, vol. 20, pp. 1131-38.

5. E. Nelson: World Conf. ADI, Oct. 27-28, 2016, pp. 1-6.

6. M. Bamberger: Encyclopedia of Iron, Steel and Their Alloy, 5th ed., Taylor and Francis, New York, NY, 2016, pp. 196-216.

7. Y. Tanaka and H. Kage: Mater. Trans. JIM, 1992, vol. 33, pp. $543-57$.

8. A. Boccardo, M. Dardati, D.J. Celentano, L.A. Godoy, M. Gorny, and E. Tyrała: Metall. Mater. Trans. B, 2016, vol. 47B, pp. $566-75$.

9. A.D. Boccardo, P.M. Dardati, L.A. Godoy, and D.J. Celentano: Metall. Mater. Trans. B, 2018, vol. 49B, pp. 1522-36.

10. W. Kapturkiewicz, E. Fraś, and A.A. Burbelko: Mater. Sci. Eng. $A$, 2005, vols. 413-414, pp. 352-57.

11. T.N. Rouns, K.B. Rundman, and D.M. Moore: AFS Trans., 1984, vol. 121, pp. 815-40.

12. W. Dubensky and K.B. Rundman: AFS Trans., 1985, vol. 93, pp. 389-94.

13. B. Bosnjak, B. Radulovic, K. Pop-Tonev, and V. Asanovic: $J$. Mater. Eng. Perform., 2001, vol. 10, pp. 203-11.

14. N. Darwish and R. Elliott: Mater. Sci. Technol., 1993, vol. 9, pp. $572-85$.

15. N. Darwish and R. Elliott: Mater. Sci. Technol., 1993, vol. 9, pp. 586-602.

16. N. Darwish and R. Elliott: Mater. Sci. Technol., 1993, vol. 9, pp. 882-89.

17. R. Donnini, A. Fabrizi, F. Bonollo, F. Zanardi, and G. Angella: Metall. Mater. Int., 2017, vol. 23, pp. 855-64.

18. E. Fraś, M. Górny, E. Tyrała, and H.F. Lopez: Mater. Sci. Technol., 2012, vol. 28, pp. 1391-96.

19. M. Górny, E. Tyrała, and H.F. Lopez: J. Mater. Eng. Perform., 2014, vol. 23, pp. 3505-10.

20. J. Mallia and M. Grech: Mater. Sci. Technol., 1997, vol. 13, pp. $408-14$

21. K.L. Hayrynen and J. Keough: AFS Trans., 2005, vol. 113, pp. $803-12$.
22. S. Biswas, C. Monroe, and T. Prucha: Int. J. Met., 2017, vol. 11, pp. 656-74.

23. F. Zanardi: Metall. Ital., 2005, vol. 10, pp. 27-32.

24. A.P. Druschitz and D.C. Fitzgerald: SAE Trans., 2003, 2006-01-0016, pp. 1-9.

25. J.R. Keough, K.L. Hayrynen, and G.L. Pioszak: AFS Trans., 2010, vol. 10, pp. 1-15.

26. G. Nadkarni, S. Gokhale, and J. Boyd: AFS Trans., 1996, vol. 104, pp. $985-94$.

27. J. Massone, R. Boeri, and J. Sikora: Int. J. Cast Met. Res., 1996, vol. 9, pp. 79-82.

28. J. Massone, R. Boeri, and J. Sikora: AFS Trans., 1996, vol. 104, pp. 133-37.

29. F.G. Caballero, M.K. Miller, S.S. Babu, and C. García-Mateo: Acta Mater., 2007, vol. 55, pp. 381-90.

30. F.G. Caballero, H.W. Yen, M.K. Miller, J.R. Yang, J. Cornide, and C. Garcia-Mateo: Acta Mater., 2011, vol. 59, pp. 6117-23.

31. F.G. Caballero, M.K. Miller, A.J. Clarke, and C. Garcia-Mateo: Scripta Mater., 2010, vol. 63, pp. 442-45.

32. F.G. Caballero, M.K. Miller, C. Garcia-Mateo, C. Capdevila, and S.S. Babu: Acta Mater., 2008, vol. 56, pp. 188-99.

33. F.G. Caballero, M.K. Miller, and C. Garcia-Mateo: J. Mater. Sci., 2008, vol. 43, pp. 3769-74.

34. M. Baricco, G. Franzosi, R. Nada, and L. Battezzati: Mater. Sci. Technol., 1999, vol. 15, pp. 643-46.

35. M.J. Pérez, M.M. Cisneros, E. Valdés, H. Mancha, H.A. Calderón, and R.E. Campos: J. Mater. Eng. Perform., 2002, vol. 11, pp. 519-26.

36. J. Rodriguez-Carvajal: Phys. B, 1993, vol. 192, pp. 55-69.

37. M. Górny, E. Tyrała, G. Sikora, and Ł. Rogal: Met. Mater. Int., 2018, vol. 24, pp. 95-100.

38. J.A. Pero-Sanz, E.D. Fernández González, and L.F. Verdeja: Physical Metallurgy of Cast Irons, Springer, Cham, Switzerland, 2018.

39. Y. Mi: Scripta Metall. Mater., 1995, vol. 32, pp. 1313-17.

40. M.A. Yescas, H.K. Bhadeshia, and D.J. MacKay: Mater. Sci. Eng., 2001, vol. A 311, pp. 162-73.

41. A. Trudel and M. Gange: Can. Metall. Q., 1997, vol. 36, pp. 289-98.

42. T. Takahashi, T. Abe, and S. Tada: Metall. Mater. Trans. A, 1996, vol. $27 \mathrm{~A}$, pp. $1589-98$.

43. G.K. Williamson and W.H. Hall: Acta Metall. Mater., 1953, vol. 1 , pp. $22-31$.

44. K.B. Rundman: 35th Australian Foundry Institute National Conf, Australian Foundry Institute, Adelaide, Australia, 2004.

45. X. Li, J.N. Wagner, A. Stark, R. Koos, M. Landesberger, M. Hofmann, G. Fan, W. Gan, and W. Petry: Metals, 2019, vol. 9, p. 789.

46. M. Górny, G. Angella, E. Tyrała, M. Kawalec, S. Paź, and A. Kmita: Met. Mater. Int., 2019, vol. 25, pp. 956-65.

Publisher's Note Springer Nature remains neutral with regard to jurisdictional claims in published maps and institutional affiliations. 